\title{
Regulation of the abundance of clover seed weevils, Apion spp. (Coleoptera: Curculionidae) in a seed stand of red clover (Trifolium pratense L.)
}

\author{
P. Kolařík, J. Rotrekl \\ Agriculture Research, Ltd., Department of Plant Protection, Troubsko, Czech Republic
}

\begin{abstract}
The clover seed weevils, Apion trifolii and Protapion apricans, members of the genus Apion, are responsible for causing serious economic damage in clover. In 2010-2012, the effectiveness of some insecticides against clover seed weevils in the genus Apion were tested in red clover stands. The efficacy of different products was evaluated on the basis of analyses of specimens trapped in the herb layer of red clover using a sweep net and red clover heads sampled in individual plots. Over the course of these trials, the applications of the products tested resulted in a marked reduction in their numbers (particularly of adults and, to a lesser extent, also of larvae). The highest efficacy was observed with Biscaya 240 (A.I. thiacloprid) and Mospilan 20 SP (A.I. acetamiprid). Results obtained in this study corroborated the low efficacy of the insecticide Karate Zeon Technology 5 CS against seed weevils of the genus Apion.
\end{abstract}

\section{Introduction}

In the Czech Republic, red clover (Trifolium pratense L.) and alfalfa (Medicago sativa L.) are among the most frequently cultivated fodder crops. They are grown mainly for production of green fodder and

Correspondence: Pavel Kolařík, Agriculture Research Ltd., Department of Plant Protection, Zahradní 1, Troubsko 664 41, Czech Republic.

Tel.: +420547138835 - Fax: +420547138800 .

E-mail: kolarik@vupt.cz

Key words: plant protection, insecticides, insect pests, red clover, clover seed weevils, Apion spp.

Funding: this study was supported by financial resources granted by the research organization Agriculture Research, Ltd., Troubsko.

Received for publication: 13 March 2013.

Revision received: 24 June 2013.

Accepted for publication: 28 June 2013.

(C) Copyright P. Kolař́k and J. Rotrekl, 2013

Licensee PAGEPress, Italy

Journal of Entomological and Acarological Research 2013; 45:e19

doi:10.4081/jear.2013.e19

This article is distributed under the terms of the Creative Commons Attribution Noncommercial License (by-nc 3.0) which permits any noncommercial use, distribution, and reproduction in any medium, provided the original author(s) and source are credited. seed material. In 2011, the total acreage of red clover stands approved for seed production was only 4491 ha; compared with the preceding year; this was a reduction of approximately 10\% (Rotrekl \&, Kolařík 2011). However, red clover, with its 57\% share of fodder crops grown is a dominant species among other seed producing stands of forage legumes; e.g., alfalfa, sanfoin, crown vetch, etc. (Kolařík \& Rotrekl, 2012a, 2012c). In the production of red clover, it is especially important to observe all technological measures concerning seed-producing stands, as this is the only way to obtain high yields of seeds (Rotrekl, 2000). There are several general rules that should be followed; e.g., selection of a suitable seed material (variety) and a locality with good potential conditions for high yields; it is also necessary to minimize the damage caused by insect pests. Many pesticides that were used earlier in legume and pulse crops have been gradually eliminated and their registrations are now cancelled. Registration of new products occurs only sporadically (Anonymous, 2008; Kolařík \& Rotrekl, 2012a).

The clover seed weevils Apion trifolii (L.) and Protapion apricans (Herbst), members of the genus Apion, are pests that damage most clover stands (Hansen \& Boelt, 2008; Lundin et al., 2012; Rotrekl, 2000). These species are closely related, their bionomics is similar, and they co-occur on red clover (Kolařík \& Rotrekl, 2012c). Adults survive the winter in different sites, and in spring they migrate to clover stands, where they feed on leaves, into which they bore small circular or oval holes. In May, they begin to lay eggs into green but not flowering heads during the period when the first rosy petals start to appear. First-instar larvae feed on the basal parts of the flower; they damage ovaries and developing seeds and migrate (climb) to neighboring florets in the head. A developing larva can destroy an average of 7-11 florets. Infested inflorescences are much smaller and develop into a hard, knotty mass. After finishing their development, larvae pupate and a new generation of beetles hatches in June and July (Hansen \& Boelt, 2008; Ma et al., 2012; Lundin et al., 2012; Rotrekl, 2000). Larvae cause the most significant damage and significantly reduce seed yield (Hansen \& Boelt, 2008; Ma et al., 2012). To minimize damage and protect the crops, both agrotechnical (cultural) and chemical methods of control may be used (Kolařík \& Rotrekl, 2012a, 2012c).

Agrotechnical measures involve selection of a locality suitable for production of seed material and also possessing a protective buffer zone. The stand for seed production should not be established near storehouses of dry clover or in the neighborhood of older clover stands, which should be plowed. After the first cutting, it is also appropriate to preserve a small part of the buffer zone, in which seed weevils can lay their eggs; after the end of flowering, this buffer stand can be mowed and the harvested forage destroyed so that the developing pests are killed. In addition, the blooming buffer stands can attract insects, which after the cutting can continue to visit and pollinate flowers of the second growth (Kolařík \& Rotrekl, 2012c).

To protect clover stands against seed weevils, it is necessary to monitor and predict their occurrence for an indication of a need for treat- 
ment of the infested crops. Pest incidence may not be harmful every year, but in some years (e.g., 2010) they can occur in very high numbers or even exhibit mass outbreaks. Prognosis should be made before the first cutting, with the detection of 350 adults per 100 samples during the flowering period indicating a potentially harmful level of these pests. All stands with more than 200 adults per 100 samples at the beginning of the flowering period should be treated (Anonymous, 2008; Kolařík \& Rotrekl, 2012a, 2012c). Currently, the product Karate Zeon Technology $5 \mathrm{CS}$ at a rate of $0.2 \mathrm{l} / \mathrm{ha}$ is the only insecticide approved for protection of seed production stands against these pests in the Czech Republic (Anonymous, 2008).

\section{Materials and methods}

\section{Experimental sites}

Experiments to assess the effectiveness of some selected insecticides against seed weevils in the genus Apion were carried out during 2010-2012. In 2010, the experimental site was located near the village of Litostrov ( $\left.49^{\circ} 13 ’ 22.868^{\prime \prime} \mathrm{N} ; 6^{\circ} 20^{\prime} 11.868^{\prime \prime} \mathrm{E}\right)$ and the individual treatments were: Treatment 1 - untreated control; Treatment 2 Mospilan 20 SP (A.I. acetamiprid - 20\%) at $150 \mathrm{~g} / \mathrm{ha}$; Treatment 3 Mavrik 2 F (A.I. tau-fluvalinate $240 \mathrm{~g} / \mathrm{L}$ ) at $0.2 \mathrm{~L} / \mathrm{ha}$; Treatment 4 Biscaya $240 \mathrm{OD}$ (A.I. thiacloprid $240 \mathrm{~g} / \mathrm{l}$ ) at $0.3 \mathrm{~L} / \mathrm{ha}$; and Treatment 5 Karate Zeon Technology 5 CS (A.I. lambda-cyhalothrin $50 \mathrm{~g} / \mathrm{L}$ ) at 0.2 L/ha. In 2011, the experimental site was near the village of Lesní Hluboké (49 ${ }^{\circ} 16^{\prime} 13.167^{\prime \prime} \mathrm{N} ; 16^{\circ} 18$ '50.952" E) and the treatments tested were: Treatment 1 - untreated control; Treatment 2 - Proteus 110 OD (A.I. thiacloprid $100 \mathrm{~g} / \mathrm{L}+$ deltamethrin $10 \mathrm{~g} / \mathrm{L}$ ) at $0.5 \mathrm{~L} / \mathrm{ha}$; Treatment 3 - Mospilan $20 \mathrm{SP}$ at $150 \mathrm{~g} / \mathrm{ha}$; Treatment 4 - Biscaya OD 240 at $0.3 \mathrm{~L} / \mathrm{ha}$; and Treatment 5 - Karate Zeon Technology 5 CS at $0.2 \mathrm{~L} / \mathrm{ha}$. In 2012, the experimental site was again near the 2011 site $\left(49^{\circ} 16^{\prime} 7.719^{\prime \prime} \mathrm{N}\right.$; $16^{\circ} 18^{\prime} 40.217^{\prime \prime} \mathrm{E}$ ) and the treatments were the same as in 2011 (except for Treatment 2 , in which Proteus 110 OD was applied at $0.75 \mathrm{~L} / \mathrm{ha}$ ). In all years, the surfactant Silwet Star was applied with all insecticide treatments at a rate of $0.06 \mathrm{~L} / \mathrm{ha}$.

\section{Evaluation of adults and larvae}

The total area of individual treatment plots ranged from 1-5 ha. Based on the results of monitoring, application of the insecticides tested was made from immediately before flowering to the appearance of the first florets. Immediately before treatment, samples of weevils present in the herb layer of clover stands were taken using a sweep net. Samples comprised four replicates of 10 net sweeps per treatment. The collected insects were killed in the laboratory by fumigation with ethyl acetate, and counted on filter paper under a stereoscope. A post-treatment evaluation of adults and larvae present in the plots was conducted using the same procedure. Approximately one month after treatment, 100 clover heads were collected randomly in individual treatments and examined in the laboratory for the presence of seed weevil larvae.

Effectiveness of the different treatments was evaluated statistically using the formula of Henderson \& Tilton (1955), and the numbers of adults were compared with the untreated control. Average numbers of larvae per head were assessed in each treatment as well. After desiccation of the individual stands, plants from a $0.25-\mathrm{m}^{2}$ area were collected in four different sites of each treatment, for a total plot area sampled of $1 \mathrm{~m}^{2}$. Plant samples were processed in the laboratory and the seed material obtained was cleaned and weighed. Projected seed yields per hectare were calculated (excluding field effects) for each treatment. We assessed the following parameters: thousand grain weight (TGW), germination energy, and germination rate of collected seed samples. TGW was calculated from the proportion of pure seeds in 4 reps of 1000 seeds sampled. Germination energy and germination rate were calculated from 4 samples of 100 seeds taken 4 and 10 days after the establishment of the of germination tests.

\section{Results}

\section{0 trial}

In 2010, a high incidence of seed weevils in the genus Apion was observed before the first application of insecticides (Figure 1). On average, the abundance of seed weevils was approximately 1650 specimens per 100 sweep net samples. Treatments were applied on 9 July, late in the afternoon. At the time of application, the weather was sunny and very hot $\left(26.7^{\circ} \mathrm{C}\right)$. Because the specific recommendations concerning the application of pyrethroid insecticides were not observed, their efficacy might have been negatively influenced.

Evaluation of the incidence of insects $3 \mathrm{~d}$ after insecticide application showed the highest abundance of clover seed weevils per 100 samples to be in Treatment 5 (the standard, Karate Zeon Technology 5 CS). In the other treatments, pest incidence was low, and ranged from zero in Treatment 4 (Biscaya 240 OD) to 10 adults in the two remaining treatments. In Treatments 2-4, a high level of efficacy was observed, ranging from 98.9 to $100 \%$ mortality (Figure 2).

On the final evaluation date, 19 July (10 days after application), the highest numbers of adults were found in Treatment 5 , which was the

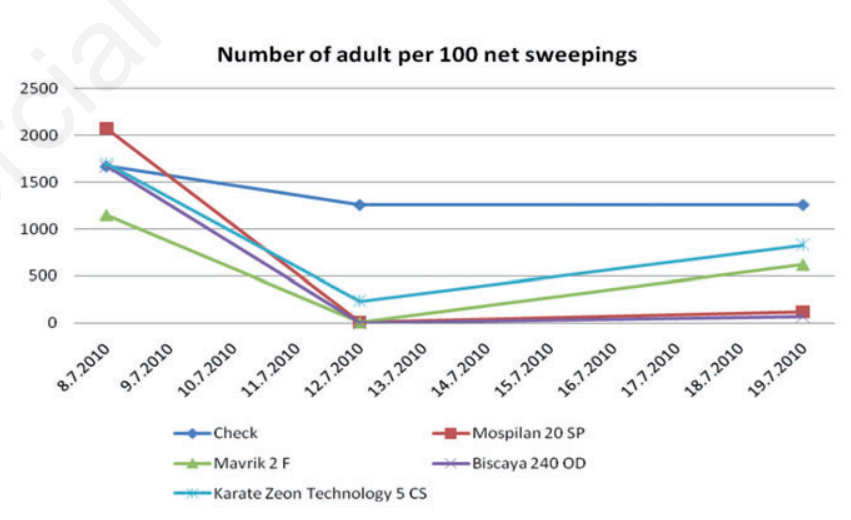

Figure 1. Effect of individual insecticides on the abundance of clover seed weevils in 2010.

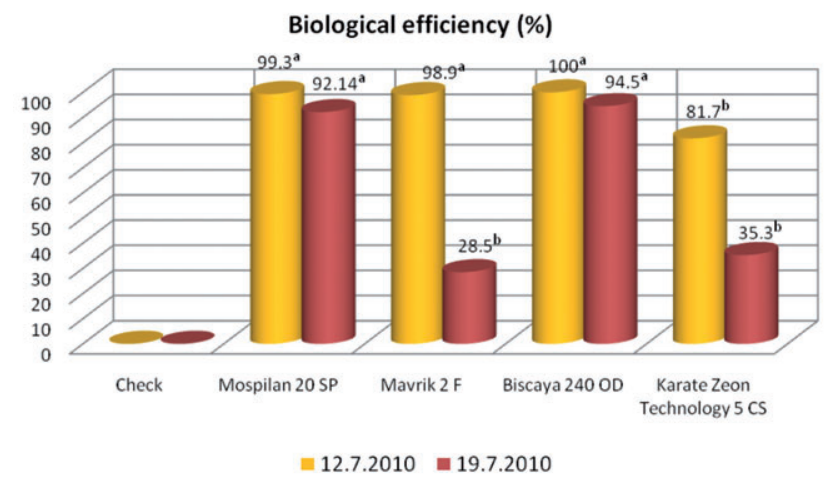

Figure 2. Biological efficiency of the insecticides tested in 2010. 
registered standard, Karate Zeon Technology 5 CS (F=196.935). Very low efficacy was also observed in Treatment 3 , the pyrethroid Mavrik 2 F (28.5\%). The lowest incidence of clover seed weevils was detected in Treatment 4 (Biscaya 240 OD) and Treatment 3 (Mospilan 20 SP). In 2010 , during which there were very high populations of seed weevils in clover stands, the efficacy of both products was excellent, ranging from 92.2 to $94.5 \%$ mortality. The difference between these treatments and both the standard (Treatment 5) and the untreated control (Treatment 1) was statistically highly significant $(F=196.935)$. In evaluation of clover heads, the highest number of larvae per head (4.5) was found in the untreated control. Among the treated plots, the highest numbers of larvae per clover head (3.6) were in Treatments 5 and 2 (Karate Zeon technology $5 \mathrm{CS}$ and Mavrik $2 \mathrm{~F}$, respectively). In the remaining treatments, the incidence of seed weevil larvae was low. The difference between these two treatments and other treatments tested was statistically highly significant $(\mathrm{F}=13.671)$.

\section{1 trial}

In 2011, the pre-treatment incidence of clover seed weevils was not as high as in 2010. The incidence of pests in the individual treatments averaged 518 per 100 samples; however, this number still exceeded the

Number of adult per 100 net sweepings

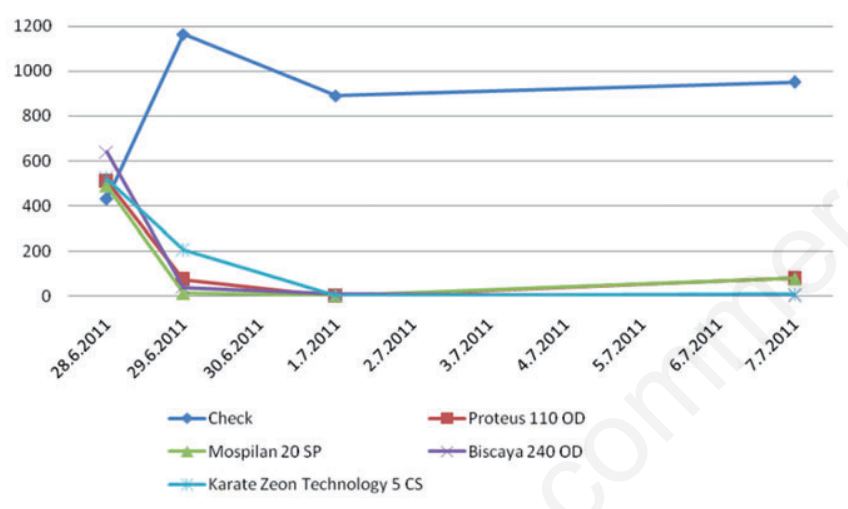

Figure 3. Effect of application of insecticides on abundance of seed weevils in 2011 .

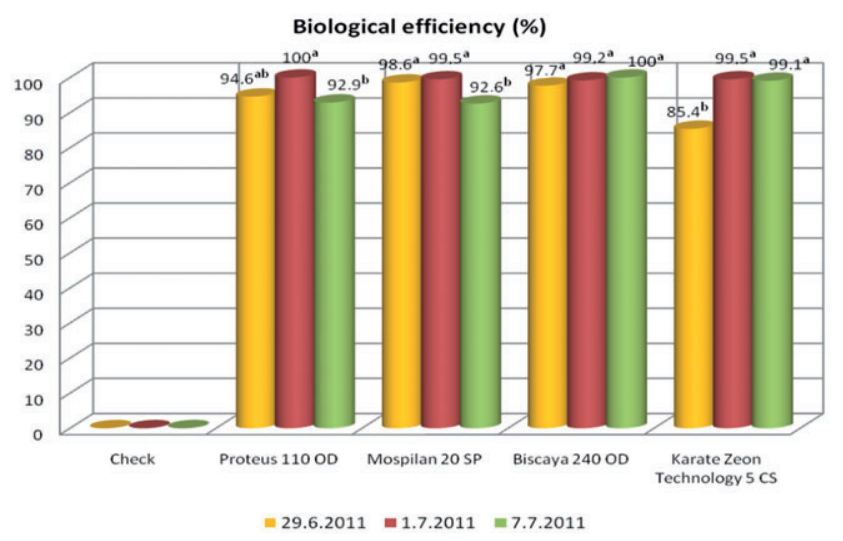

Figure 4. Biological efficiency of the insecticides tested in 2011. economic threshold for this pest in stands of red clover (Figure 3). In the individual treatments, weevil samples were collected and analyzed $3 \mathrm{~d}$ after the insecticide applications. Treatments were applied on 28 June. The greatest number of adults was recorded in the untreated check, while in all treated plots the pest incidence was very low. This was reflected in the observed efficacies of the individual insecticides, which ranged from $99.2 \%$ (Biscaya 240 OD) to 100\% (Proteus 110 OD). In contrast to 2010, the only currently registered product, Karate Zeon technology $5 \mathrm{CS}$, showed high insecticidal activity (Figure 4).

Ten days after application, there was a significant difference in numbers of adults between the untreated control and all treated plots $(\mathrm{F}=539.310)$. In these treatments, insecticide efficacy was very high, ranging from 92.6\% (Mospilan $20 \mathrm{SP}$ ) to 100\% (Biscaya $240 \mathrm{OD}$ ). Evaluation of larvae in the clover heads showed no statistically significant difference between the control and Karate Zeon Technology 5 CS. This product did not have any effect on larval incidence in the clover heads, despite the fact that it killed the adults very effectively. In other treatments, numbers of larvae were very low, particularly in Treatment 4 (Mospilan 20 SP) and Treatment 3 (Biscaya 240 OD). Again, the difference between the unregistered products (Treatments 2-4) and Treatments 5 and 1 (the standard insecticide and the untreated control, respectively) was statistically highly significant. No significant differences were found among the remaining treatments $(\mathrm{F}=34.979)$.

\section{2 trial}

In 2012, the pre-treatment pest incidence averaged 659 specimens per 100 samples (Figure 5). This high incidence could have been influenced by the fact that the trials were carried out in the same locality as in the preceding year, with the fields separated only by a rural road, so that the beetles could have migrated easily to the experimental plots.

Treatments were applied on 29 June. One day after application, a high efficacy of the products applied was observed in all treatments, with values ranging from $85.4 \%$ (Treatment 5) to $98.6 \%$ mortality (Treatment 2). Five days after application, the number of clover seed weevils increased significantly in Treatment 5 , translating into an efficacy of only $28 \%$. On the last assessment date (14 days after application), the highest efficacy was recorded in Treatment 2 (98.2\%) and Treatment 3 (96.6\%). Very good efficacy was observed also in remaining treatments (Figure 6).

Efficacy of Karate Zeon Technology 5 CS was very low, with incidence of the seed weevils much higher than in the control. The difference between Treatments 2-4 and Karate was statistically highly significant ( $F=138.676)$. On 8 August, analysis of the clover heads revealed the highest number of larvae in Karate Zeon Technology 5 CS. The lowest numbers of larvae were recorded in Treatments 3 and 4 . Again, the difference between Treatments 2-4 and Treatments 1 and 5 was statistically highly significant $(\mathrm{F}=18,450)$.

In 2012 , seed yields were evaluated shortly before harvest of all treatments. The lowest yield was recorded in Treatment 5 (Karate Zeon Technology 5 CS) and the highest were in Treatments 3 and 4 (Table 1). Differences between Treatments 1 and 5 and the remaining test treatments (Treatments 2-4) were statistically highly significant $(\mathrm{F}=106.489)$. The qualitative analysis of harvested seed material did not show any differences in TGW ( $\mathrm{F}=2.437)$, germination energy $(\mathrm{F}=2.776)$ or germination rate $(\mathrm{F}=2.381)$ between Treatments $2-4$ collectively, and Treatments 1 and 5 .

\section{Discussion and conclusions}

Due to restrictions on the application of older insecticides containing less suitable active ingredients, the only approved applicable for- 
Table 1. Evaluation of yield - 2012.

\begin{tabular}{|c|c|c|c|c|c|}
\hline Variants & $\begin{array}{c}\text { Energy of } \\
\text { germination (\%) }\end{array}$ & $\begin{array}{l}\text { Germination } \\
\qquad \%)\end{array}$ & TGW & $\begin{array}{c}\text { Yield } \\
\text { per } 1 \text { head (g) }\end{array}$ & $\begin{array}{l}\text { Total yield } \\
\text { (kg/ha) }\end{array}$ \\
\hline Check & 69 & 70.8 & 1.7005 & 0.065 & 552.32 \\
\hline Proteus 110 OD & 69 & 71 & 1.61475 & 0.086 & 733.4 \\
\hline Biscaya 240 OD & 81.3 & 83.5 & 1.7068 & 0.101 & 863.1 \\
\hline Mospilan 20 SP & 62.3 & 63.8 & 1.5915 & 0.099 & 845.88 \\
\hline Karate Zeon Technology 5 CS & 75 & 77.3 & 1.5533 & 0.057 & 485.81 \\
\hline
\end{tabular}

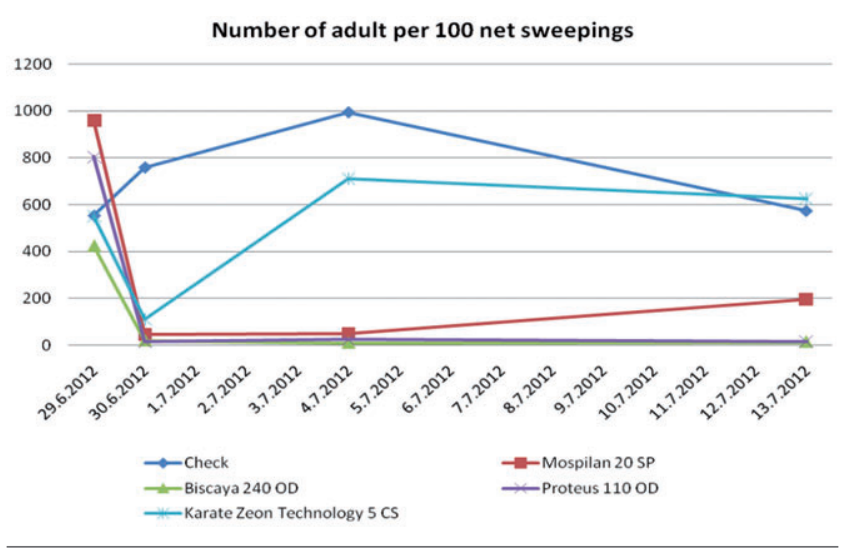

Figure 5. Effect of individual insecticides on the abundance of clover seed weevils in 2012.

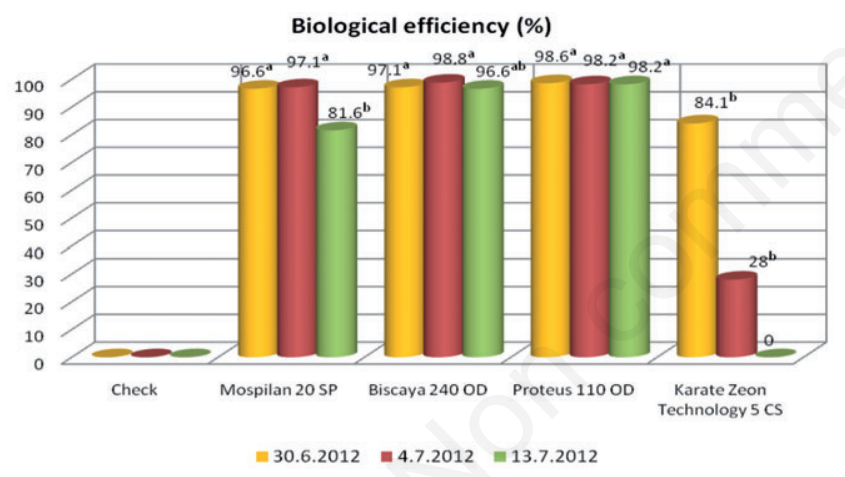

Figure 6. Biological efficiency of the insecticides tested in 2012.

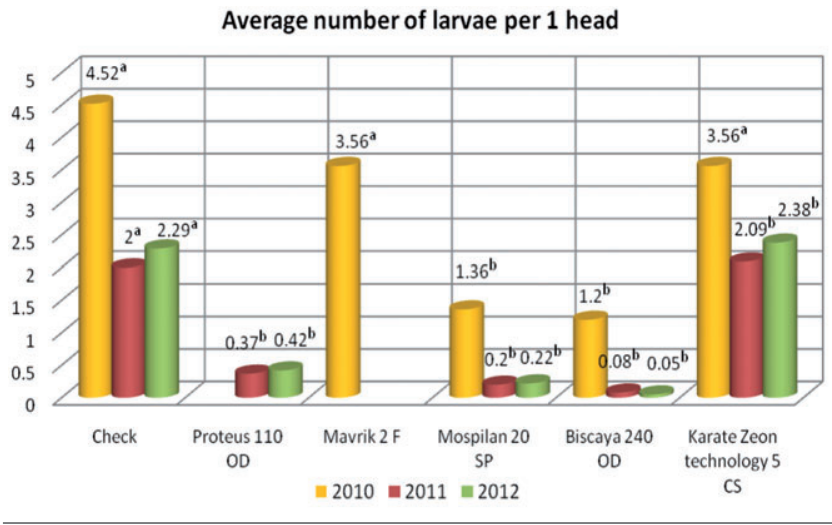

Figure 7. Average number of larvae per 1 head (2010-2012). mulation was the single registered pyrethroid, Karate Zeon Technology 5 SC (Anonymous, 2008; Kolařík \& Rotrekl, 2012a, 2012c). The effectiveness of this product can be especially influenced by weather conditions at the time of application, as it is known that efficacy of pyrethroids is markedly influenced by high temperatures and solar UV radiation (Kolařík \& Rotrekl, 2012b; Ma et al., 2012).

These products can completely lose their efficacy, enabling insect pests to continue to survive and feed, so that a grower expecting such an application to prevent seed yield losses will not be successful if the application takes place on an unsuitable date. In stands of red clover, seed weevils of the genus Apion represent the most important group of insect pests (Hansen \& Boelt, 2008; Kolařík \& Rotrekl, 2012a; Rotrekl \& Kolařík, 2011; Langer \& Rohde, 2008) and can markedly decrease yields of clover seed material (Langer \& Rohde, 2008; Lundin et al., 2012). Over the course of these trials, application of the products tested resulted in a marked reduction of their numbers, particularly of adults, and to a lesser extent, also of larvae (Figure 7). The highest efficacy was observed from Biscaya 240 (thiacloprid) and Mospilan 20 SP (acetamiprid). These products are relatively new insecticides that show both contact and systemic activity and belong to the class of neonicotinoids (Cloyd \& Bethke, 2011). These insecticides' efficacy is not dependent on weather conditions, and they show good residual activity on both adults and larvae, even at higher temperatures. Pyrethroids are only contact insecticides, and their residual effect on adults is relatively short (Kolařík \& Rotrekl, 2012b; Lundin et al., 2012).

Our results corroborated the low efficacy of Karate Zeon Technology $5 \mathrm{CS}$ against seed weevils of the genus Apion. There were no significant differences in seed yields between this treatment and the untreated control. Compared with the control, plots treated with the neonicotinoid products showed seed yields equivalent to $300 \mathrm{~kg}$ per ha. The difference between these products and the pyrethroid was statistically highly significant as well. It should be noted that no negative effects of these treatments on plants, beneficial species or honey bees were observed during the experimental period, and that their numbers remained high after applications of the products tested.

\section{References}

ANONYMOUS, 2008. - Metodická příručka ochrany rostlin proti chorobám, škůdcům a plevelům. I. Polní plodiny. - Česká společnost rostlinolékařská, Praha: 504.

CLOYD R.A., BETHKE J.A., 2011. - Impact of neonicotinoid insecticides on natural enemies in greenhouse and interiorscape environments. - Pest. Manag. Sci. 67: 3-9.

HANSEN L.M., BOELT B., 2008. - Thresholds of economic damage by clover seed weevil (Apion fulvipes Geoff.) and lesser clover leaf weevil (Hypera nigrirostris Fab.) on white clover (Trifolium repens L.) seed crops. - Grass Forage Sci. 63: 433-437.

HENDERSON C.F., TILTON E. W., 1955. - Tests with acaricides against the brow wheat mite. - J. Econ. Entomol. 48:157-161. 
KOLARIKK P., ROTREKL J., 2012a. - Ochrana semenných porostů jetele lučního proti hmyzím škůdcům. - Agromanuál 6: 36-37.

KOLAŘÍK P., ROTREKL J., 2012b. - Rezistence škodlivých organismů vůči pesticidům. -Úroda 12 , vědecká příloha: 43-48.

KOLAŘIIK P., ROTREKL J., 2012c. - Výskyt nosatčíků rodu Apion vjeteli lučním a nové možnosti jejich regulace. - Pícninářské listy 28 : 36-38.

LANGER V., ROHDE B., 2008. - Factors reducing yield of organic white clover seed production in Denmark. - Grass Forage Sci. 60: 168-174.

LUNDIN 0., RUNDLÖF M., SMITH H.G., BOMMARCO R., 2012. -
Towards integrated pest management in red clover seed production. - J. Econ. Entomol. 105: 1620-1628.

MA Y.H., GAO Z.L., DANG Z.H., LI Y.F., PAN W.L., 2012. - Effect of temperature on the toxicity of several insecticides to Apolygus lucorum (Heteroptera: Miridae). - J. Pest. Sci. 37: 135-139.

ROTREKL J., 2000. - Zemědělská entomologie. - Mendelova zemědělská a lesnická univerzita vBrně: 84.

ROTREKL J., KOLAŘÍK P., 2011. - Významní hmyzí škůdci vsemenných porostech jetele lučního. - Agromanuál 7: 32-33. 